\title{
Effects of chlordecone on 20-hydroxyecdysone concentration and chitobiase activity in a decapod crustacean, Macrobrachium rosenbergii
}

\author{
Anne Lafontaine ${ }^{\mathrm{a}, *}$, Eric Gismondi $^{\mathrm{a}}$, Céline Boulangé-Lecomte ${ }^{\mathrm{b}}$, Perrine Geraudie ${ }^{\mathrm{c}}$, \\ Nathalie Dodet ${ }^{\mathrm{a}}$, Fanny Caupos ${ }^{\mathrm{d}, \mathrm{e}}$, Soazig Lemoine ${ }^{\mathrm{d}}$, Laurent Lagadic ${ }^{\mathrm{e}}$, \\ Jean-Pierre Thomé ${ }^{\mathrm{a}}$, Joëlle Forget-Leray ${ }^{\mathrm{b}}$ \\ a University of Liège, Laboratory of Animal Ecology and Ecotoxicology (LEAE), Centre of Analytical Research and Technology (CART), 15 Allée du Six Aout, \\ B-4000 Liège, Belgium \\ ${ }^{\mathrm{b}}$ Normandie University, ULH, UMR I-02, Environmental Stresses and Biomonitoring of Aquatic Ecosystems (SEBIO)-FR CNRS 3730 SCALE, 25 rue Philippe \\ Lebon, F-76600 Le Havre, France \\ c Akvaplan-Niva (Norwegian Institute of Water Research) AS, Fram Centre, 9296 Tromsoe, Norway \\ d DYNECAR-UMR BOREA (MNHN/CNRS 7208/IRD207/UPMC), University of the French West Indies and Guiana, Campus de Fouillole, Pointe-à-Pitre, \\ Guadeloupe F-97110, France \\ e INRA, UMR0985 Ecology and Ecosystem Health Research Unit, Ecotoxicology and Quality of Aquatic Environments Research Group, 65 rue de Saint Brieuc, \\ F-35042 Rennes, France
}

\section{A R T I C L E I N F O}

\section{Article history:}

Received 8 December 2015

Received in revised form 1 April 2016

Accepted 5 April 2016

Available online 6 April 2016

\section{Keywords:}

Chlordecone

Macrobrachium rosenbergii

20-Hydroxyecdysone

Chitobiase

Endocrine disruptors

\begin{abstract}
A B S T R A C T
Chlordecone (CLD) is an organochlorine insecticide abundant in aquatic environment of the French West Indies. However, few studies have investigated its impact on freshwater invertebrates. Whereas CLD is suspected of inducing endocrine disruption, this work aimed to study the effects of environmentally relevant concentrations of CLD on the 20-hydroxyecdysone (20-HE) hormone concentration and on the chitobiase activity, both having key roles in the molting process of crustaceans. In addition, the bioaccumulation of CLD was measured in the muscle tissue of Macrobrachium rosenbergii to underline potential dose-response relationship. The results have shown that CLD was bioaccumulated in exposed organisms according to a trend to a dose-response relationship. Moreover, it was observed that CLD decreased the 20-HE concentration in exposed prawns when compared to control, whatever the duration of exposure, as well as it inhibited the chitobiase activity after 30 days of exposure. The present study indicates that CLD could interfere with molting process of $M$. rosenbergii by disturbing the 20-HE concentration and the activity of chitobiase, suggesting consequences at the long term on the shrimp development. This study also confirmed that CLD could be an endocrine disruptor in decapod crustaceans, as it was already observed in vertebrates.
\end{abstract}

(c) 2016 Elsevier B.V. All rights reserved.

\section{Introduction}

Endocrine disrupting compounds (EDCs) are exogenous substances or mixtures able to interfere with the endocrine system of exposed organisms. They could affect the hormonal signaling pathways through several mechanisms, for example by inhibiting the synthesis of hormones or decreasing the hormone release by endocrine cells (Craig et al., 2011; Tabb and Blumberg, 2006;

\footnotetext{
* Corresponding author at: Laboratory of Animal Ecology and Ecotoxicology (LEAE), University of Liège, Bât. B6C, 15, Allée du 6 Aout, B-4000 Liège, Belgium.

E-mail address: Anne.Lafontaine@ulg.ac.be (A. Lafontaine).
}

Rodríguez et al., 2007). EDCs can also disrupt hormone-receptor interactions and act as an agonist or antagonist by binding to the hormone-receptor complex (Rodríguez et al., 2007; Tabb and Blumberg, 2006). Aquatic environments are considered the main sink for contaminants (Kloas et al., 2009; Meyer-Reil and Köster, 2000), and thus aquatic organisms are therefore major potential targets for EDCs (Kloas et al., 2009).

Several studies on the biological effects of EDCs in aquatic vertebrates have led to the development of biomarkers in order to measure the biological responses towards anthropogenic pollutions, such as changes in the reproductive function. For example, Jobling and Sumpter (1993) introduced the concept that the production of vitellogenin $(\mathrm{Vg})$ in male fish indicates an exposure 
to estrogenic compound and $\mathrm{Vg}$ is now a widely used biomarker of xenoestrogen exposure in vertebrates. Although EDC effects have been extensively described in aquatic vertebrates (Kortenkamp et al., 2011; LeBlanc, 2007), only few studies have examined the effects of EDCs in invertebrates, although they represent the major part of the animal kingdom (DeFur et al., 1999). This lack could be partially due to the fact that the endocrine system of invertebrates is still obscure (Tillmann et al., 2001). It has nevertheless been observed that EDCs can also disrupt invertebrate physiology. For example, Giusti et al. (2013) have shown that tributyltin affected the production of yolk ferritin (i.e. Vg equivalent) in Lymnaea stagnalis, and Xuereb et al. (2011) observed that nonylphenol (estrogenic compound) impacted the expression of a vitellogeninlike gene in the amphipod Gammarus fossarum. It appears that vitellogenin-like proteins in invertebrates could serve as biomarkers of EDC exposure, but mechanisms involved in Vg production in invertebrates are still unclear (e.g. hormonal receptor).

EDCs can come from different sources such as synthetic hormones (e.g. ethinylestradiol), synthetic substances (e.g. plasticizers such as phthalates, herbicides) and pesticides often used to eradicate insects. In the French West Indies (FWI), the tropical climate promotes the rapid development of pests which exerts significant pressure on crops leading to the use of considerable amounts of pesticides in these regions (Bocquené and Franco, 2005). The use of organochlorine pesticides first started in the 1950's and led to widespread contamination of the environment (Coat et al., 2006). Because of their physicochemical properties, organochlorine pesticides are persistent in the environment and are known to be accumulated along food chains, resulting in pronounced ecotoxicological damage (Cailleaud et al., 2009; Matsumura, 1975). The most worrying organochlorine pesticide residue in Guadeloupe (FWI) is chlordecone (CLD) (Coat et al., 2011). CLD is an insecticide that was commonly employed to control the banana weevil Cosmopolites sordidus from 1972 to 1993 under the trade name Kepone ${ }^{\circledR}$ or Curlone ${ }^{\circledR}$ (Cabidoche et al., 2006, 2009). A few years after the use of CLD, widespread pollution of soils, rivers, wild animals and aquatic organisms was reported (Cavelier, 1980; Snegaroff, 1977), which led to the prohibition of the use of this pesticide in Guadeloupe in 1993. Moreover, in 2009, CLD was included in the Stockholm Convention on POPs (Persistent Organic Pollutants) and its production and use were banned worldwide (Zaldivvar and Baraibar, 2011). Nowadays, CLD is still present in soils, especially in the densely cultivated areas from south of Basse-Terre (Guadeloupe) (Cabidoche et al., 2009). Although, Fernández-Bayo et al. (2013) showed the existence of CLD degrading organisms in a tropical soil (andosol) microcosm under aerobic conditions, CLD undergoes no significant or quick biotic or abiotic degradation (Dolfing et al., 2012; Levillain et al., 2012). Driven by the water cycle, CLD in soils is progressively transferred to aquatic ecosystems (Coat et al., 2011) and also in the food web because of its high $\mathrm{K}_{\mathrm{oc}}$ (Soil Organic Carbon Water Partitioning Coefficient) $\left(15849 \mathrm{~L} / \mathrm{Kg}\right.$ ), $\mathrm{K}_{\text {ow }}$ (Octanol-Water Partition Coefficient) (4.5-6.0) and its affinity for lipids (Cabidoche and Lesueur-Jannoyer, 2012; Clostre et al., 2013; Sterrett and Boss, 1977; UNEP, 2005; US-EPA, 2008). Human contamination has also been detected in FWI population mainly resulting from consumption of contaminated food, seafood and root vegetables (Dubuisson et al., 2007; Gaume et al., 2014; Guldner et al., 2010). Fishing became prohibited when most aquatic species have exceeded the European legal maximal residual limit (LMR) of $20 \mu \mathrm{g}$ of CLD per $\mathrm{kg}$ wet weight (determined by National ordinance, Anon., 2008). Until 2008, one of the most important aquaculture resources in Guadeloupe was the farms of the tropical giant freshwater prawn Macrobrachium rosenbergii. Several studies have underlined effects of pesticides on this species (Revathi and Munuswamy, 2010; Satapornvanit et al., 2009), but very few investigations were carried on the CLD impacts on M. rosenbergii. However, Gaume et al.
(2014) have observed that the CLD exposure caused the induction of genes involved in defense mechanisms against oxidative stress (e.g. catalase and glutathione peroxidase), or involved in the biotransformation process (i.e. cytochrome P450 and glutathioneS-transferase).

As CLD is suspected of being an endocrine disruptor (Newhouse et al., 2009) and as M. rosenbergii molting is hormonally controlled, the present study aims to investigate the CLD impact on the molting process by investigating the effects of CLD on the concentration of the 20-Hydroxyecdysone (20-HE) hormone and on chitobiase activity in tissues of $M$. rosenbergii. The 20-HE hormone is an ecdysteroid hormone, secreted by the Y-organ (Mykles, 2011), which initiates many physiological processes, such as ovarian maturation, growth, molting, and reproduction in crustaceans (LeBlanc, 2007). A few studies have been designed to investigate the effects of exposure to environmental EDCs on the endocrine system of crustaceans through ecdysteroid concentration, or to investigate the endocrine system of invertebrates (Oberdörster et al., 1999; Palma et al., 2009; Soetaert et al., 2007), but no studies have used the 20-HE concentration to investigate the effects of chlordecone.

Chitobiase is a chitinolytic enzyme involved in the exoskeleton degradation in arthropods and thus plays an important role in the molting and growth of crustaceans (Duchet et al., 2011; Zou and Fingerman, 1999a). Several studies have demonstrated that chitinolytic enzymes are induced by the 20-HE hormone (Zou and Fingerman, 1999b). However, many pollutants have been also shown to induce the chitobiase enzyme. Indeed, Zou and Fingerman (1999c) observed that some estrogenic agents, such as Aroclor 1242, diethylstilbestrol or endosulfan, inhibited chitobiase activity of the crustacean Uca pugilator. Similarly, Gismondi and Thomé (2014) noted that some pollutants, suspected of being EDCs (i.e. polybromodiphenyl ethers), could disturb the chitobiase activity of the amphipod Gammarus pulex.

Finally, in parallel with these two parameters, the bioaccumulation of CLD in $M$. rosenbergii was evaluated to underline potential concentration-response relationships between the CLD concentration in tissues, the 20-HE concentration and the chitobiase activity. These measures ensure assessing the molting disruption, called the invisible endocrine disruption, because of the disruption of the crustacean molting which is not readily seen in the wild (Zou, 2005).

\section{Materials and methods}

\subsection{Tested organisms}

The 3-month-old post-larvae of $M$. rosenbergii (approximately $2 \mathrm{~g}, 7 \mathrm{~cm}$ length and sexually undifferentiated) coming from the same berried female, were provided by an aquaculture farm (OCEAN-SA) located at Pointe-Noire (Guadeloupe, FWI) in a geographic area free of CLD contamination. Pretests have previously been carried out to evaluate the presence or absence of CLD in tissues of prawns from Pointe-Noire and results have shown no contamination (concentrations below detection limit) (data not shown). Prawns were then transferred to the laboratory (DYNECAR, University of the French West Indies and Guiana, Guadeloupe), and acclimated for one week in glass aquaria filled with $28 \mathrm{~L}$ of tap water prefiltered on activated carbon. Aquaria were under constant aeration with a $12 \mathrm{~h}$ light/dark photoperiod. During acclimation, prawns were fed once daily with artificial shrimp pellets (complete food for rearing, Le Gouessant, France) at one pellet per individual. A constant water temperature of $27.6 \pm 0.2^{\circ} \mathrm{C}$ was maintained, and $\mathrm{pH}$ remained at $7.57 \pm 0.03$ throughout the experiment. These values are in accordance with optimal water temperature and $\mathrm{pH}$ commonly used in prawn farms (New, 2002). Survival was 
$96.3 \pm 3.8 \%$ throughout the experiment, regardless of the conditions.

\subsection{Experimental design}

The $10 \mathrm{mg} \mathrm{mL}^{-1}$ stock solution of CLD (100\%, Riedel-de-Haën, Sigma-Aldrich, USA) was prepared in acetone as were also its three different dilutions: $10 \mu \mathrm{g} \mathrm{mL}^{-1}, 100 \mu \mathrm{g} \mathrm{mL}^{-1}$ and $1 \mathrm{mg} \mathrm{mL}^{-1}$. A volume of $56 \mu \mathrm{L}$ of each dilution and of the stock solution was diluted into the $28 \mathrm{~L}$ of aquarium water in order to obtain the four nominal concentrations of CLD in water: $0.02 \mu \mathrm{g} \mathrm{L}^{-1}, 0.2 \mu \mathrm{g} \mathrm{L}^{-1}, 2 \mu \mathrm{g} \mathrm{L}^{-1}$ and $20 \mu \mathrm{g} \mathrm{L}^{-1}$. These concentrations were chosen because of their environmental relevance. According to the Guadeloupean DIREN (Regional Department for the Environment), Guadeloupean rivers are contaminated by CLD at concentrations that range from 0.2 to $4 \mu \mathrm{gL}^{-1}$ with a maximum of $8.6 \mu \mathrm{g} \mathrm{L}^{-1}$ measured in the Grande Anse River in 2003 (GREPP, 2004; InVS-Inserm, 2009).

In this experimental design, two different controls were used. The first, called "water control", was tap water prefiltered through activated carbon; and the second, called "solvent control", was obtained by spiking $28 \mathrm{~L}$ of prefiltered tap water with $56 \mu \mathrm{L}$ of acetone. Ten aquaria were used for each condition of exposure. During the 30 days of exposure, $M$. rosenbergii were fed daily with artificial shrimp pellets (complete food for rearing, Le Gouessant, France), with one pellet per individual. Waste was removed every day prior to feeding. Based on the results of a pre-test designed to evaluate the concentration of CLD in water according to the duration of exposure, it was decided to renew the exposure medium every $96 \mathrm{~h}$, over a total exposure time of 30 days. This process allowed to maintain constant concentrations of CLD during the 30 days of exposure.

A total of 360 post-larvae of $M$. rosenbergii coming from the same berried female and having the same age (see Section 2.1), were exposed (i.e. 36 prawns per condition) for 30 days, which is the duration of two molt cycles (Ross, 2001). At the beginning of the exposure (T0), prawns of $M$. rosenbergii were in premolt stage, confirmed by the measurement of the 20-HE concentration in 12 prawns randomly sampled before exposure (i.e. $2058.61 \pm 371.66 \mathrm{pg} \mathrm{g}^{-1}$ ). This concentration corresponds to the peak reached by the 20 -HE hormone during the molt cycle (see below the confirmation by results of 20 -HE concentration in both controls from 1 to 15 days and from 15 to 30 days, corresponding to one molt cycle each). Fifteen $M$. rosenbergii were randomly sampled for each condition, after four durations of exposure: 1, 4, 15 and 30 days. Five prawns (corresponding to 5 replicates) were used for the CLD bioconcentration assessments, and ten prawns (corresponding to 10 replicates) were used to measure the $20-\mathrm{HE}$ concentration as well as the chitobiase activity. After sampling, the prawns were immediately frozen in liquid nitrogen and stored at $-80^{\circ} \mathrm{C}$ until analyses. Before analyses, body length was measured and no significant difference (two-way ANOVA test, $\mathrm{p}>0.05$ ) was observed between groups (Supplementary material 1).

\subsection{Chlordecone concentration in exposure water and $M$. rosenbergii}

\subsubsection{Chlordecone extraction from water}

The CLD concentration was analyzed in aquarium water by liquid-liquid extraction. A volume from $10 \mathrm{~mL}$ to $1 \mathrm{~L}$ of water (according to the CLD concentration) was collected and $5 \mathrm{~mL}$ of dichloromethane (Biosolve-Chimie, France) was added. Then, $50 \mu \mathrm{L}$ of acetonic solution of PCB112 (100 pg $\mu \mathrm{L}^{-1}$ ) (Dr. Ehrenstorfer, Germany), used as surrogate internal standard, were added before the extraction procedure. This internal surrogate was used in order to quantify possible loss of CLD during the extraction and purification procedures. The organic phase was recovered and then a purification procedure was performed (see Section 2.3.3).

\subsubsection{Chlordecone extraction from muscle tissue}

The CLD concentration was analyzed in abdominal muscle of $M$. rosenbergii according to a method derived from Debier et al. (2003), Multigner et al. (2010) and Lagarrigue et al. (2014). Prawns were thawed, and approximately $500 \mathrm{mg}$ of muscle tissue was freeze-dried during $20 \mathrm{~h}$ with a Benchtop $3 \mathrm{~L}$ Sentry Lyophilisator (VirTis, USA). The lyophilized samples were weighed in order to determine water content. The extraction of CLD was performed with a solvent mixture of $n$-hexane: dichloromethane (90:10; v:v; Biosolve-Chimie, France) using an Accelerated Solvent Extractor (ASE200) (Dionex, Thermo Scientific, USA) at $80^{\circ} \mathrm{C}$ and under a pressure of 1500 Psi. Before the extraction, $100 \mu \mathrm{L}$ of a hexanic solution of PCB congener 112 (Dr. Ehrenstorfer, Germany) was added to the samples as a surrogate internal standard to obtain a final concentration of $50 \mathrm{pg} \mathrm{\mu L}^{-1}$. Then, $500 \mathrm{mg}$ of anhydrous sodium sulfate were added to avoid any water trace in the extract. The solvent, containing the extracted fat, was collected in pre-weighed vials and evaporated at $40^{\circ} \mathrm{C}$ under a gentle nitrogen flow using a Turbovap LV (Zymarck, USA) until a constant weight of residues. Then, the lipid content was determined gravimetrically.

\subsubsection{Sample purifications}

The purification step was the same for water and biological samples. The residues from the two different extraction were resuspended into $2 \mathrm{~mL}$ of $n$-hexane (Biosolve-Chimie, France) and transferred into a test tube to carry out an acid clean-up. A volume of $2 \mathrm{~mL}$ of $98 \%$ sulfuric acid (Merck, Germany) was added in the extracts in order to remove organic matter (e.g. lipids, lipoproteins, carbohydrates). The mixture was homogenized by vortexing for 1 min with a Vibramax 110 (Heidolph, Germany), and centrifuged for $3 \mathrm{~min}$ at $2160 \mathrm{~g}, 10^{\circ} \mathrm{C}$. The organic phase was collected into a new tube and the sulfuric acid layer was extracted in the same way with another $3 \mathrm{~mL}$ of $n$-hexane to ensure an optimal recovery. The two resulting organic layers were pooled and $5 \mu \mathrm{L}$ of nonane were added as a keeper. This extract was evaporated under a gentle nitrogen stream using a Visidry evaporator (Supelco, Sigma-Aldrich, USA) before being resuspended with $45 \mu \mathrm{L}$ of $n$-hexane and $50 \mu \mathrm{L}$ of a solution of PCB 209 (100 pg $\mu \mathrm{L}^{-1}$ in $n$-hexane) as an injection volume internal standard (Dr. Ehrenstorfer, Germany).

In parallel with sample extractions, a procedural blank and a Quality Control (QC) were carried out. The procedural blank consisted of the ASE extraction without biological matrix, allowing to control the extraction and the clean-up procedure. The $\mathrm{QC}$ was performed to assess the CLD recovery by using a CLD-free water or biological matrix (here, freeze-dried muscle of the decapod Penaeus monodon) spiked with an acetonic solution of CLD in order to obtain a final concentration of $2.5 \mathrm{ng} \mathrm{L}^{-1}$ for water and $2.5 \mathrm{ng} \mathrm{g}^{-1}$ wet weight for biological sample. Muscle tissue of $P$. monodon was used here as biological matrix of decapod because they came from geographic area free of CLD contamination.

\subsubsection{Chromatography analysis}

The purified extracts, procedural blank and QC were analyzed by high-resolution gas chromatography using a Thermo Quest Trace 2000 gas chromatograph equipped with a ${ }^{63} \mathrm{Ni}$ ECD detector (Thermo Scientific, USA) and an auto-sampler Thermo Quest AS 2000 (Thermo Scientific, USA). The extract was injected in the on-column mode at $60^{\circ} \mathrm{C}$. CLD was separated on a $30 \mathrm{~m} \times 0.25 \mathrm{~mm}$ ( $0.25 \mu \mathrm{m}$ film) DB-XLB capillary column (J\&W Scientific, USA). The other analytical parameters were described elsewhere (Lagarrigue et al., 2014; Multigner et al., 2010). Data were recorded with Chromcard 2.8 (Fisons Instruments, Italy) software for Windows. CLD was identified based on its retention time previously determined 
Table 1

Chlordecone concentration (mean \pm S.D.) measured in water of exposure. LOQ means limit of quantification $\left(0.01 \mathrm{ng} \mathrm{L}^{-1}\right)$.

\begin{tabular}{|c|c|c|c|c|c|c|}
\hline Conditions: & Watercontrol & Solvent control & $0.02 \mu \mathrm{g} \mathrm{L}^{-1}$ & $0.2 \mu \mathrm{g} \mathrm{L}^{-1}$ & $2 \mu \mathrm{g} \mathrm{L}^{-1}$ & $20 \mu \mathrm{g} \mathrm{L}^{-1}$ \\
\hline Nominal concentration $\left(\mu \mathrm{g} \mathrm{L}^{-1}\right)$ & 0 & 0 & 0.020 & 0.20 & 2.00 & 20.00 \\
\hline Measured concentration $\left(\mu \mathrm{g} \mathrm{L}^{-1}\right)$ & $<$ LOQ & $<\mathrm{LOQ}$ & $0.019 \pm 0.002$ & $0.20 \pm 0.03$ & $1.80 \pm 0.13$ & $20.43 \pm 2.56$ \\
\hline
\end{tabular}

Table 2

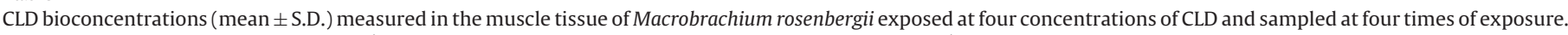

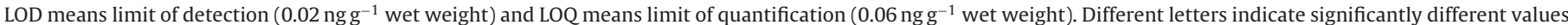
for each CLD concentration of exposure. Tukey's HSD test was performed with the log-transformed CLD concentration ( $\mathrm{p}$-values < 0.05 ).

\begin{tabular}{|c|c|c|c|}
\hline Nominal Concentration $\left(\mu \mathrm{g} \mathrm{L}^{-1}\right)$ & Time (days) & Chlordecone concentration in muscle tissue $\left(\mathrm{ng} \mathrm{g}^{-1}\right)$ & $\mathrm{BCF}$ \\
\hline Control & $\begin{array}{l}1 \\
4 \\
15 \\
30\end{array}$ & $\begin{array}{l}<\text { LOD } \\
<\text { LOQ } \\
<\text { LOQ } \\
<\text { LOQ }\end{array}$ & $\begin{array}{l}1 \\
1 \\
1 \\
1\end{array}$ \\
\hline Solvent Control & $\begin{array}{l}1 \\
4 \\
15 \\
30\end{array}$ & $\begin{array}{l}<\text { LOD } \\
<\text { LOQ } \\
<\text { LOQ } \\
<\text { LOQ }\end{array}$ & $\begin{array}{l}1 \\
1 \\
1 \\
1\end{array}$ \\
\hline 0.02 & $\begin{array}{l}1 \\
4 \\
15 \\
30\end{array}$ & $\begin{array}{l}1.58 \pm 1.09^{a} \\
4.20 \pm 3.34^{b} \\
5.08 \pm 1.13^{b} \\
30.80 \pm 10.37^{c}\end{array}$ & $\begin{array}{l}79 \\
210 \\
254 \\
1540\end{array}$ \\
\hline 0.2 & $\begin{array}{l}1 \\
4 \\
15 \\
30\end{array}$ & $\begin{array}{l}10.56 \pm 1.64^{\mathrm{a}} \\
7.89 \pm 1.68^{\mathrm{a}} \\
38.12 \pm 13.48^{\mathrm{b}} \\
45.96 \pm 34.09^{\mathrm{b}}\end{array}$ & $\begin{array}{l}53 \\
39 \\
191 \\
230\end{array}$ \\
\hline 2 & $\begin{array}{l}1 \\
4 \\
15 \\
30\end{array}$ & $\begin{array}{l}36.06 \pm 11.90^{\mathrm{a}} \\
27.66 \pm 5.01^{\mathrm{a}} \\
241.52 \pm 127.38^{\mathrm{b}} \\
845.15 \pm 374.31^{\mathrm{c}}\end{array}$ & $\begin{array}{l}32 \\
14 \\
121 \\
423\end{array}$ \\
\hline 20 & $\begin{array}{l}1 \\
4 \\
15 \\
30\end{array}$ & $\begin{array}{l}292.75 \pm 133.11^{a} \\
547.36 \pm 228.74^{a} \\
26637.37 \pm 12411.53^{b} \\
5312.04 \pm 2683.82^{c}\end{array}$ & $\begin{array}{l}15 \\
27 \\
1332 \\
266\end{array}$ \\
\hline
\end{tabular}

with a linear calibration curve (1.5 to $200 \mathrm{pg} \mu \mathrm{L}^{-1}$ ) established with certified solutions of CLD (Riedel-de Haën, Germany). The CLD concentrations in each sample and in the QC were corrected with the percentage recovery of the surrogate $\mathrm{PCB} 112$. The recovery efficiency based on the CLD recovery in QC and on the recovery of the surrogate internal standard (PCB112) ranged from $88 \pm 4 \%$ to $115 \pm 5 \%$, which was within the limits recommended by SANCO (i.e. range from 60 to 140\% - Document No SANCO/12495/2011 European Union, 2011). The limit of detection (LOD) was fixed at three times the background noise of the chromatogram (i.e. $0.005 \mathrm{ng} \mathrm{L}^{-1}$ for water sample and $0.02 \mathrm{ng} \mathrm{g}^{-1}$ wet weight for muscle tissue). The limit of quantification (LOQ) was determined with CLD-free water or freeze-dried prawn muscle spiked with various concentrations of CLD and was established at $0.01 \mathrm{ng} \mathrm{L}^{-1}$ for water sample and $0.06 \mathrm{ng} \mathrm{g}^{-1}$ wet weight for muscle tissue, corresponding to about ten times the background noise of the chromatogram. The CLD concentrations in water and in muscle tissue of $M$. rosenbergii were measured in five replicates per condition and the mean calculated. The CLD concentrations expressed in $\mu \mathrm{g} \mathrm{L}^{-1}$ for water sample are presented in Table 1 and in ng g $^{-1}$ wet weight for biological sample are presented in Table 2 . The bioconcentration factor (BCF) was calculated for each condition using the method of Taylor (1983) described in Duquesne et al. (2000) (Table 2). BCF is the ratio between CLD concentration in muscle tissues of prawns and CLD concentration in tank water.

\subsection{0-Hydroxyecdysone concentration}

The concentrations of the 20-HE hormone and its derivatives (called "20-HE" in the following text, figures and tables) were measured by following the manufacturer's instructions of the Enzyme ImmunoAssay (EIA) kit (Cayman Chemical Company, USA) which were adapted to our biological organism (e.g. weight of tissue, solvent of homogenization, standard curve). Muscle tissue was chosen as biological matrix in order to be consistent with the tissue used for the CLD concentration assessment. In addition, a pretest, which investigated the 20HE concentration in different organs, showed that the muscle tissue has a high 20 -HE concentration (see Supplementary material 2). A weight of $250 \mathrm{mg}$ of frozen muscle tissue of $M$. rosenbergii was homogenized in $2: 1(\mathrm{w}: \mathrm{v})$ of methanolwater $(4: 1, \mathrm{v}: \mathrm{v})$ (i.e. $500 \mu \mathrm{L}$ of methanol-water to $250 \mathrm{mg}$ of tissue) using a Precellys homogenizer (Bertin Technologies, France). Samples were incubated overnight at $-20^{\circ} \mathrm{C}$ and centrifuged for $10 \mathrm{~min}$ at $10,000 \mathrm{~g}$ and $4{ }^{\circ} \mathrm{C}$. The resulting supernatant was transferred into a glass tube and the solvent was evaporated with a CentriVap Centrifugal Vacuum Concentrator combined with a CentriVap Cold Trap (Labconco, USA) using centrifugal force, vacuum and controlled temperature. After evaporation, samples were resuspended in EIA Buffer (1 M phosphate, containing 1\% BSA, $4 \mathrm{M}$ sodium chloride, $10 \mathrm{mM}$ EDTA, and $0.1 \%$ sodium azide).

A 96-well microplate precoated with mouse anti-rabbit IgG (Cayman Chemical Company, USA) was used. Each microplate contained blanks (i.e. appropriated substrate solution), diluted samples in EIA Buffer in duplicate, and an eight point 20-HE (Sigma-Aldrich, USA) standard curve (of 7.8125-1000 $\mathrm{pg} \mathrm{mL}^{-1}$ ). Each sample received a solution of 20-HE EIA Antiserum (Cayman Chemical Company, USA) containing anti-20-HE rabbit IgG. Then, a solution of 20-HE Acetylcholinesterase (AChE) EIA Tracer (Cayman Chemical Company, USA) containing a covalent conjugate of 20-HE and electric eel AChE was added to each sample. After an 
overnight incubation at $4{ }^{\circ} \mathrm{C}$, the plate was washed with Wash Buffer (4 M phosphate, pH 7.4). Next, Ellman's Reagent (Cayman Chemical Company, USA) was added and the plate was incubated for $2 \mathrm{~h}$ in the dark with gentle shaking. The absorbance was measured at $420 \mathrm{~nm}$ and the average of duplicates of each sample was calculated. The 20 -HE concentrations were analyzed in 10 replicates per condition (i.e. 10 samples per condition), and the results were expressed in $\mathrm{pg} \mathrm{g}^{-1}$ of fresh weight of $M$. rosenbergii muscle tissue.

\subsection{Chitobiase activity}

A weight of $50 \mathrm{mg}$ of frozen muscle tissue of $M$. rosenbergii was homogenized in $500 \mu \mathrm{L}$ of citrate phosphate buffer $(0.15 \mathrm{M}$, $\mathrm{pH}$ 5.5) using a Precellys homogeneizer (Bertin technologies, France). Samples were centrifuged for $10 \mathrm{~min}$ at $10000 \mathrm{~g}$ and $4{ }^{\circ} \mathrm{C}$, and the resulting supernatants were recovered and used to analyze the chitobiase activity. Chitobiase activity was measured using the method described by Espie and Roff (1996). The chitobiase reaction used 4-methylumbelliferyl- $N$-acetyl- $\beta$ D-glucosaminide (MUFNAG) as a substrate and generated the fluorescent 4-methylumbelliferone (MUF), which was evaluated. Measurements were carried out in 96-well microplates containing a blank (i.e. appropriated substrate solution), an eight-point MUF (Sigma-Aldrich, USA) standard curve (0-20 $\mu \mathrm{M})$, and samples in duplicate. Every sample was incubated in the dark with the substrate MUFNAG (Sigma-Aldrich, USA) for $30 \mathrm{~min}$ at $25^{\circ} \mathrm{C}$. The reaction was stopped by addition of $0.25 \mathrm{~N} \mathrm{NaOH}$ ( $\mathrm{pH} 14.1$ ). The liberated MUF was measured fluorometrically at the excitation wavelength of $360 \mathrm{~nm}$ and emission wavelength of $450 \mathrm{~nm}$. The chitobiase activity was measured in 10 replicates per conditions. Each replicate was analyzed in duplicate and the mean was calculated. In general, enzyme activities are normalized against the total protein content in sample extracts. However, as natural variation of protein contents related to physiological changes could constitute a source of variability, several studies recommended to express enzyme activity in $\mu \mathrm{mol} \mathrm{h}^{-1}$ (Owen et al., 2002; Radenac et al., 2008; Xuereb et al., 2009). Therefore, the chitobiase activity was expressed here in $\mu \mathrm{mol}$ of MUF formed per hour ${ }^{-1}$.

\subsection{Statistical analysis}

After a log-transformation of the CLD concentrations in muscle tissue, all data met normality and homogeneity of variance assumptions (Shapiro and Bartlett tests, p>0.05). For each measured parameter (i.e CLD bioaccumulation, 20-HE concentration and chitobiase activity), comparisons were performed by two-way ANOVA followed by Tukey HSD post-hoc tests. A probability value of less than 0.05 was regarded as significant.

The correlations between measured parameters were analyzed using the Pearson correlation coefficient. All tests were performed with STATISTICA 10 Software (StatSoft, 2012, Belgium).

\section{Results}

\subsection{Chlordecone concentrations in muscle tissue of M. rosenbergii}

The CLD concentrations in the muscle tissue of $M$. rosenbergii were significantly influenced by the CLD concentrations of exposure, duration of exposure and their interaction $(\mathrm{p}<0.001)$. Results shown that the CLD concentrations were below the limit of quantification in prawns from control and solvent control conditions. Moreover, the CLD bioconcentration in prawns was concentrationdependent, since prawns exposed to higher concentrations of CLD accumulated greater amounts of CLD (Table 2). The bioaccumulation of CLD in $M$. rosenbergii was also time-dependent. Indeed,

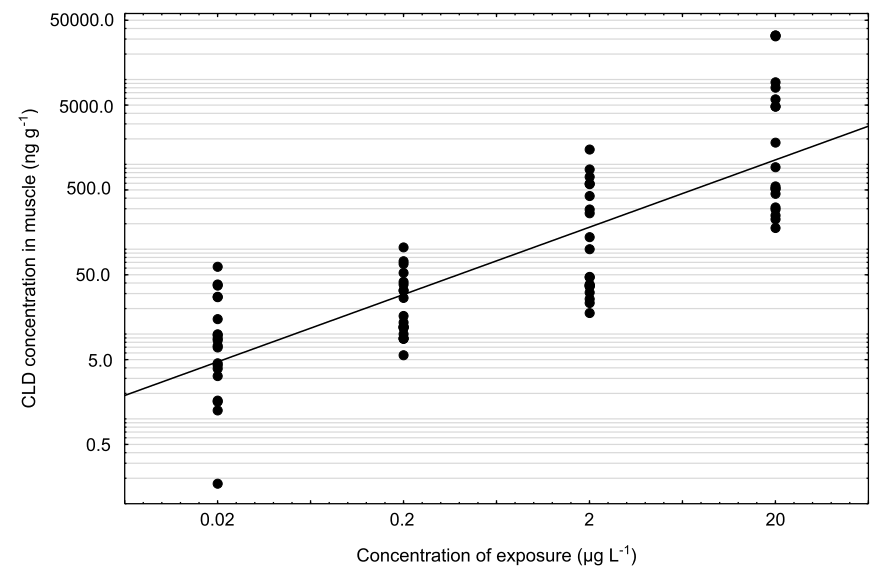

Fig. 1. Positive correlation between CLD bioconcentrations measured in the muscle tissue of Macrobrachium rosenbergii and CLD concentrations in water of exposure $(\mathrm{p}<0.001, r=0.49, \mathrm{n}=100)$, taking into account all duration of exposure.

the longer the prawns were exposed, the higher was the CLD bioconcentration. These observations were underlined by a strong significant positive correlation between concentrations of CLD in water and the CLD bioconcentration in muscle tissue of $M$. rosenbergii ( $\mathrm{p}<0.001, \mathrm{r}=0.49, \mathrm{n}=100$; Fig. 1$)$.

Generally, whatever the CLD concentration of exposure, results showed that a bioconcentration of CLD was measured from the first day of exposure (Table 2), following a trend towards a concentration-response relationship. However, no significant differences were observed in the CLD bioconcentrations after 1 and 4 days of exposure, except for exposure to $0.02 \mu \mathrm{g} \mathrm{L}^{-1}$. In addition, for each condition of exposure, the highest CLD bioconcentration measured was observed after 30 days of exposure; except for exposure to $20 \mu \mathrm{gL}^{-1}$ where the highest CLD bioconcentration was measured after 15 days of exposure (Table 2).

The bioconcentration factor (BCF) was calculated for the four CLD concentrations and results showed that BCF increased with the duration of exposure. Indeed, BCF were higher in prawns exposed for 30 days that those exposed for 1 or 4 day. Moreover, BCF appeared higher in M. rosenbergii exposed to lowest CLD concentration (i.e. $0.02 \mu \mathrm{g} \mathrm{L}^{-1}$ ) than to the other CLD concentrations.

\subsection{0-Hydroxyecdysone concentration}

Results highlighted a natural variation of the 20-HE concentration in control prawns according to the time. Indeed, the 20-HE concentration decreased between the 1 st and the 4th day of exposure, and increased between the 4 th and the 15th day (Fig. 2). In addition, no significant differences were observed between 20-HE concentrations measured in water control and in solvent control $(p>0.05)$ regardless of the duration of the exposure.

Results revealed that 20 -HE concentration was significantly influenced by the CLD concentration, the duration of exposure and their interaction. Generally, lower 20-HE concentrations were seen in exposed prawns compared to the respective control, regardless of the duration of exposure, except after 4 days of exposure. Results also showed that 20-HE concentrations seemed generally lower after 4 days of exposure compared to exposures lasting for 1,15 or 30 days. For each duration of exposure, the largest decrease of 20HE concentration was measured in prawns exposed to $0.2 \mu \mathrm{g} \mathrm{L}^{-1}$ (except after 30 days of exposure where it was the second lowest). Indeed, the 20-HE concentration was on average twice lower in this CLD concentration than in the respective controls for each duration of exposure. 


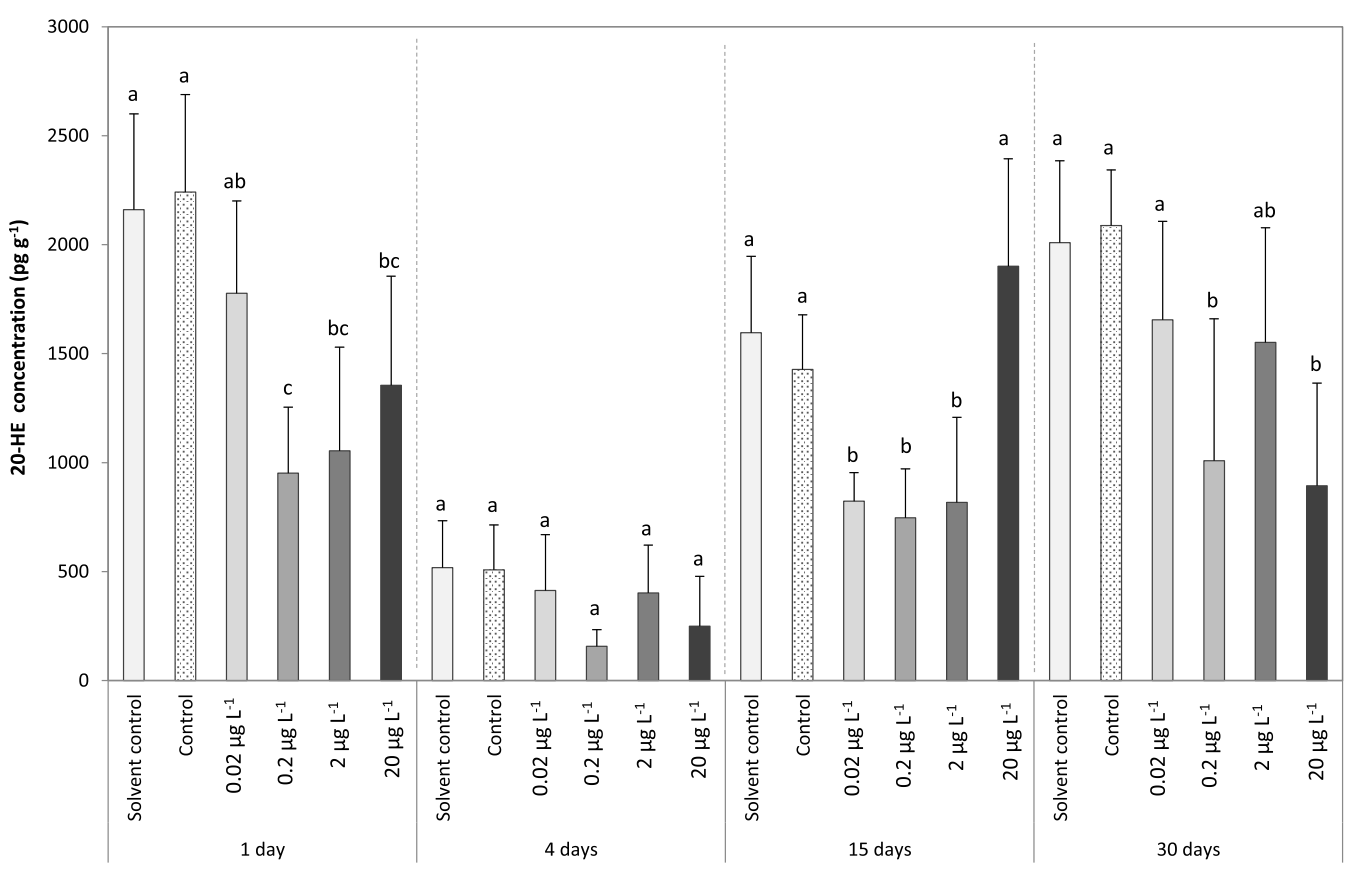

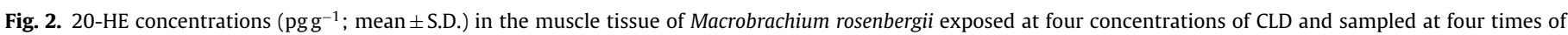
exposure. Different letters above the bars indicate significantly different values for each sampling time (Tukey's HSD test, $p$-values <0.05).

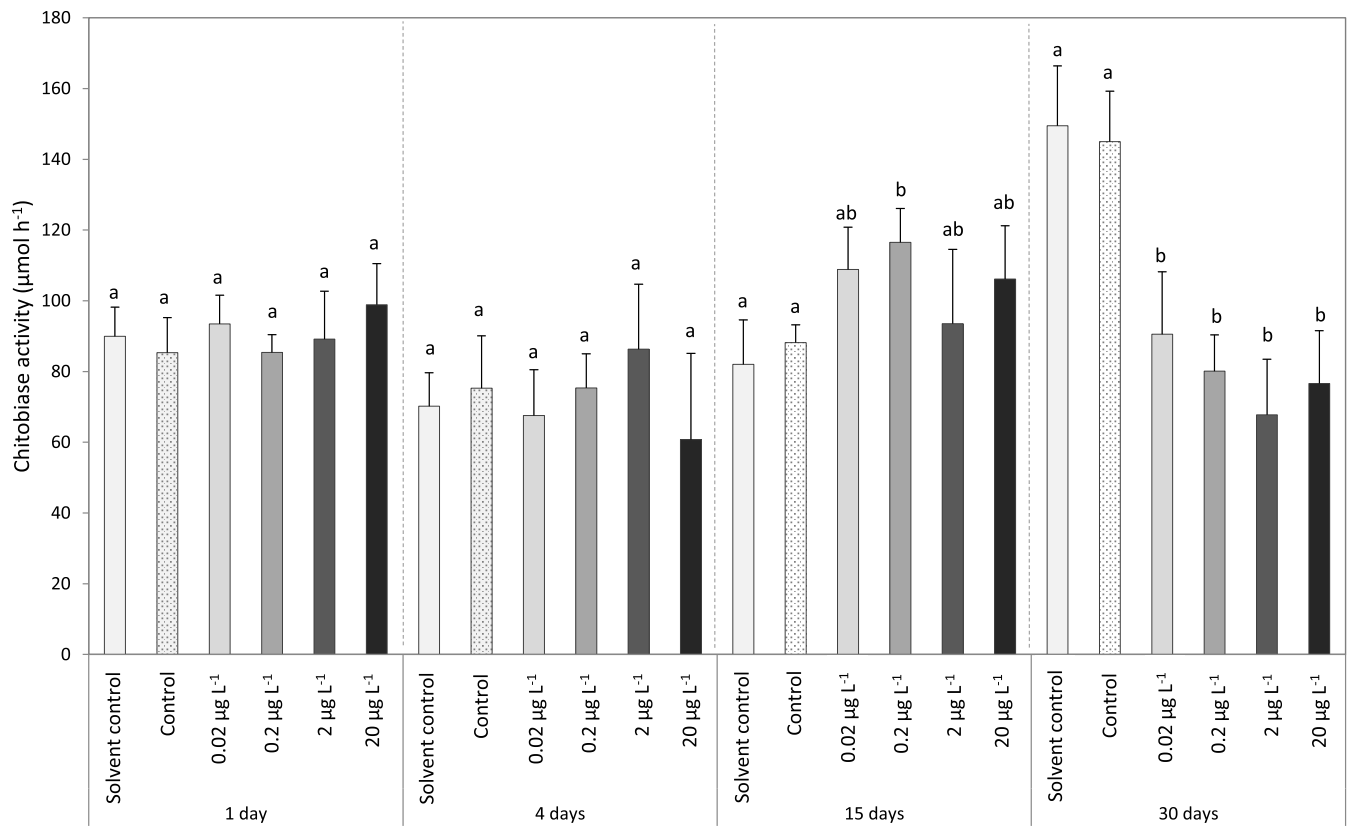

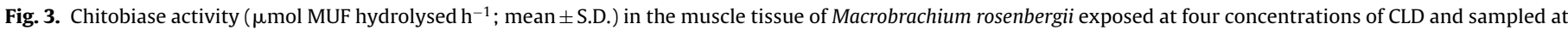
four times of exposure. Different letters above the bars indicate significantly different values for each sampling time (Tukey's HSD test, $p$-values $<0.05$ ).

After 1 day of exposure, the 20-HE concentration was significantly from 1.5 -fold to 1.8 -fold lower in $M$. rosenbergii exposed to $0.2,2$ and $20 \mu \mathrm{g} \mathrm{L}^{-1}$ of CLD compared to the control. After 4 days of exposure, although the 20-HE concentrations seemed to be lower in exposed prawns compared to the control, no significant differences were observed. However, a significant reduction of the 20 -HE concentration (on average 1.8-fold lower) was measured after 15 days of exposure in all exposure conditions compared to the control, except for $20 \mu \mathrm{g} \mathrm{L}^{-1}$. Finally, after 30 days of exposure, prawns exposed to 0.2 and $20 \mu \mathrm{g} \mathrm{L}^{-1}$ CLD had twice smaller 20-HE concentration than the control.
Moreover, a significant negative correlation between 20-HE concentration and the log-transformed CLD bioconcentrations was observed regardless of the duration of the exposure (1 day: $\mathrm{p}<0.001, \mathrm{r}=-0.87, \mathrm{n}=19 ; 4$ days: $\mathrm{p}<0.001, \mathrm{r}=-0.83, \mathrm{n}=20$; 15 days: $\mathrm{p}<0.001, \mathrm{r}=-0.76, \mathrm{n}=24 ; 30$ days: $\mathrm{p}<0.001, \mathrm{r}=-0.72$, $\mathrm{n}=21$ ) (Fig. 4).

\subsection{Chitobiase activity}

The activity of chitobiase in muscle tissue of $M$. rosenbergii was significantly influenced by the CLD concentration, the duration of exposure and their interaction ( $p<0.001$; Fig. 3$)$. The chitobiase 


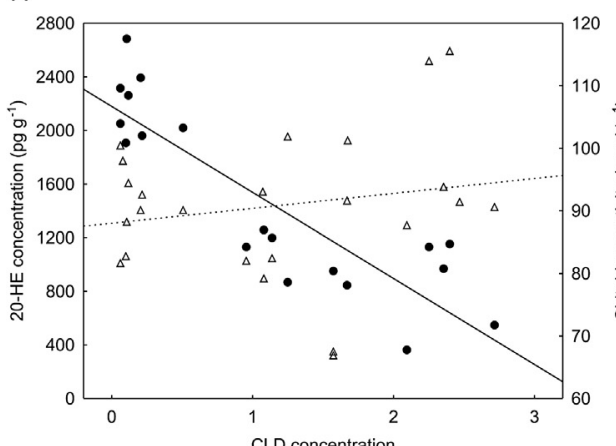

$\mathrm{C}$

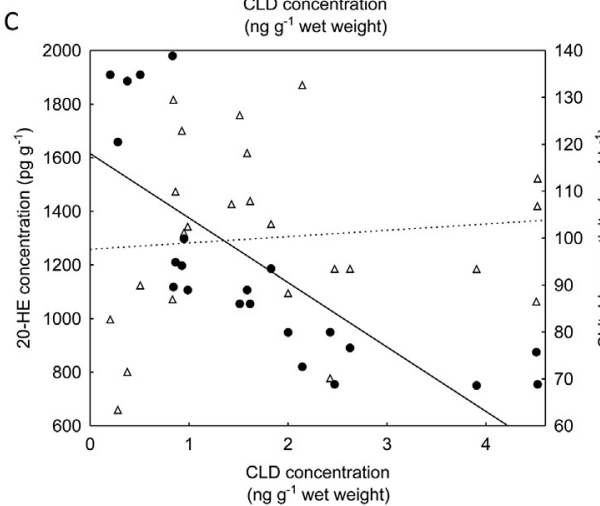

B

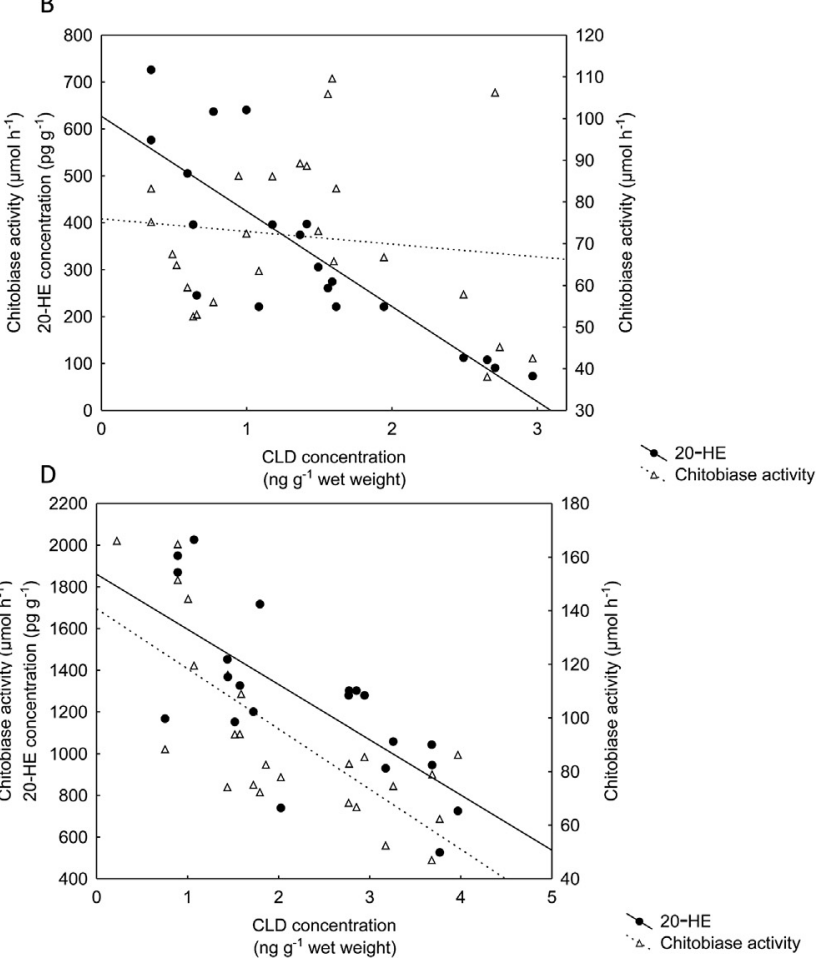

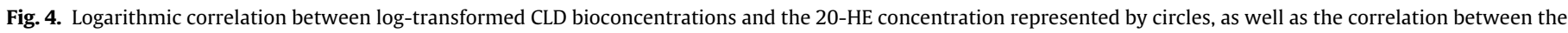

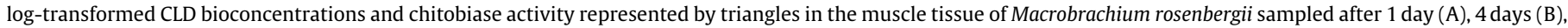
15 days (C) and 30 days (D) of exposure.

activity measured in water control and solvent control were not significantly different $(p>0.05)$ regardless of the duration of the exposure (Fig. 3). Moreover, no significant difference was observed in the chitobiase activity measured in prawns exposed to CLD for 1 and 4 days, regardless of the CLD concentration compared to the respective controls (Fig. 3). After 15 days of CLD exposure, a significant increase in the chitobiase activity was only observed in prawns exposed to $0.2 \mu \mathrm{g} \mathrm{L}^{-1}$ compared to the control. The chitobiase activity was 1.5 -fold higher than in the control prawns. On the contrary, a significant inhibition of the chitobiase activity was observed after 30 days of exposure, whatever the CLD concentration. Indeed, the chitobiase activity was in average 1.8-fold lower in exposed prawns that in the control. No correlation was observed between the chitobiase activity and the log-transformed CLD bioconcentration in prawns, expect for in prawns exposed to CLD for 30 days ( 1 day: $\mathrm{p}=0.38$; 4 day: $\mathrm{p}=0.85 ; 15$ days: $\mathrm{p}=0.65 ; 30$ days: $\mathrm{p}<0.001, \mathrm{r}=-0.74, \mathrm{n}=25$ ) (Fig. 4).

\section{Discussion}

This work aimed to study the impacts of CLD in the crustacean M. rosenbergii by measuring CLD effects on the 20-HE hormone concentration and the chitobiase activity, both involved in the molting process and thus in the growth and the development, as well as the CLD bioaccumulation in the muscle tissue of prawns.

\subsection{Chlordecone bioaccumulation}

This study highlighted that chlordecone was accumulated in tissues of $M$. rosenbergii following a trend towards a concentrationresponse relationship. The prawn survival was not affected by the CLD exposure, indicating that exposure concentrations were below lethal concentrations. Indeed, Schimmel and Wilson (1977) reported that the $96-\mathrm{h} \mathrm{LC50}$ of CLD was $121 \mu \mathrm{g} \mathrm{L}^{-1}$ for grass shrimp
Palaemonetes pugio and no significant mortality in blue crabs Callinectes sapidus at measured concentrations as high as $210 \mu \mathrm{g} \mathrm{L}^{-1}$ CLD was observed.

The bioaccumulation observed in $M$. rosenbergii is consistent with the fact that CLD has a high potential of bioaccumulation in aquatic organisms, based on its physicochemical properties (ATSDR et al., 1995). This result is in agreement with previous studies highlighting the CLD concentration in different organisms. Indeed, Van Veld et al. (1984) demonstrated that CLD could be accumulated in the channel catfish when exposed for 30 days, and Coat et al. (2011) observed the CLD bioaccumulation in tropical food web including various species of mussels, shrimps and fishes. The CLD concentrations measured in muscle tissue of $M$. rosenbergii were somewhat lower than those measured in other decapods exposed to similar CLD concentrations (Bahner et al., 1977; Gaume et al., 2014). This observation could be explained by the distribution of CLD in tissues of prawns. Indeed, because of its structure and binding properties, CLD binds preferentially to serum proteins such as lipoproteins or albumin and therefore, its distribution in the whole organism is quite different compared to other organochlorines (ATSDR et al., 1995; Newhouse et al., 2009). For example, the accumulation of CLD is highest in the liver (Newhouse et al., 2009) while other organochlorine pesticides such as HCB or p,p'-DDE are preferentially distributed in the adipose tissue (Gomez-Catalan et al., 1991; Soine et al., 1982). In addition, Roberts (1981) observed higher CLD residuals in reproductive tissues than in the hepatopancreas of the blue crabs $C$. sapidus.

Our results suggest that an accumulation of CLD was observed from the 1st day of exposure and that this increase of CLD concentrations in prawns was time-dependent from the 4th day of exposure, whatever the CLD concentration of exposure. However, in the highest CLD condition (i.e. $20 \mu \mathrm{g} \mathrm{L}^{-1}$ ), the accumulation of CLD decreased between the 15th and 30th day of exposure. This observation suggests that organisms have reached a stage beyond 
which the accumulation is no longer exponential at this concentration of exposure. Several studies have highlighted the ability of crustaceans to depurate CLD slowly (Bahner et al., 1977; Roberts, 1981; Schimmel et al., 1979). This depuration of CLD could explain the difference of CLD concentrations in M. rosenbergii between 15 and 30 days of exposure. This decrease could also be explained by a toxicity of CLD on the organism physiology, resulting in lower CLD concentration in prawns (e.g. gill destruction reducing exchange between the organism and its environment Hebel et al., 1997). Indeed, once in the organism, as most pesticides, chlordecone can exert adverse toxic effects (Sanders et al., 1981). Several studies have demonstrated that CLD could impact the crustacean development and growth through disturbance of the molting process. Indeed, Schimmel et al. (1979) showed that CLD interferes with the molting of C. sapidus. Similarly, Bookhout et al. (1980) and Oberdörster and Cheek (2001) have shown that CLD impacted the molting and the metamorphosis of $P$. pugio and Rhithropanopeus harrisii, respectively. In addition, Nimmo et al. (1977) and Sanders et al. (1981) reported that the growth of Mysidopis bahia and Gammarus pseudolimnaeus, respectively, closely linked to the molting process, was reduced by exposure to CLD. CLD could also affect the reproduction process (e.g. duration of embryonic development, the juvenile period, the reproductive and post-reproductive periods, etc.) of the rotifers of Brachionus calyciflorus as observed by Zha et al. (2007). All these results suggest that CLD accumulated in organisms could disturb critical physiological processes controlled by the hormonal system.

$\mathrm{BCF}$ results showed that the bioconcentration of CLD was more efficient with lowest concentration in water. Prawns exposed to $0.02 \mu \mathrm{g} \mathrm{L}^{-1}$ had higher BCF than prawns exposed to other CLD concentrations. Here, we can hypothesize that the higher BCF observed in the lowest CLD concentration could be explained by the potential EDC effect of CLD. Indeed, it is well known that endocrine disruption occurs with low EDC concentrations by their binding to hormonal receptors (Vandenberg et al., 2012). At an exposure concentration of $0.02 \mu \mathrm{g} \mathrm{L}^{-1}$, CLD could be sequestered in tissues as many pollutants but in addition CLD could be sequestered by receptors, resulting in higher CLD concentration in organisms. Moreover, BCF results indicated that no plateau level was reached after 30 days of exposure, especially when $M$. rosenbergii were exposed to $0.02 \mu \mathrm{g} \mathrm{L}^{-1}$, suggesting a strong accumulation of CLD in organisms exposed on the long term, which could have deleterious effects.

\subsection{Chlordecone effects on the 20-HE concentration}

In control conditions (i.e. unexposed prawns), results shown lower 20-HE concentration after 4 days of exposure compared to the other controls (i.e. 1, 15 and 30 days). This difference may be explained by the premolt stage of prawns at the beginning of the experiment and the molt cycle occurring during the experiment. Indeed, it was established that the molt cycle of $M$. rosenbergii lasts an average of 15 days (Ross, 2001). Moreover, several studies have highlighted the variation of the 20 -HE concentration during the different stages of the molt cycle of crustaceans (Hyne, 2011; Okumura and Aida, 2000; Zou and Bonvillain, 2004; Zou, 2005). The variation of 20 -HE concentration observed here could be due to variations of ecdysteroid synthesis according to the developmental stage of prawns. In crustaceans, the endocrine system regulates many processes that differentiates males from females, larvae from juveniles, and reproductively active from reproductively senescent organisms (LeBlanc, 2007). Chang and Bruce (1980) attested that ecdysteroid composition is affected by the developmental stage as well as the physiological and reproductive status of the organism. Indeed, the authors showed that the total ecdysteroid concentration in hemolymph of Homarus americanus can fluctuate during the molt cycle from less than $10 \mathrm{pg}_{\mu \mathrm{L}} \mathrm{L}^{-1}$ in postmolt to more than $350 \mathrm{pg} \mu \mathrm{L}^{-1}$ in premolt. Generally, ecdysteroid concentration is low during intermolt and postmolt, rising during premolt and reaching a peak shortly before molting (Mykles, 2011). This increase in ecdysteroid concentration is not only related to ecdysteroid synthesis but could also be explained by increased conversion of ecdysone or inactive ecdysteroids to the active form of ecdysteroids (i.e. 20HE) (Mykles, 2011).

After exposure to CLD, results revealed an effect of CLD on the 20-HE concentration. Indeed, a decrease of 20-HE in M. rosenbergii exposed to CLD was seen regardless of the concentration and the duration of exposure (except for prawns exposed to $20 \mu \mathrm{g} \mathrm{L}^{-1}$ of CLD for 15 days). This observation was supported by the fact that the 20-HE concentration and the CLD bioconcentration were significantly negatively correlated regardless of the duration of the exposure. The 20-HE disruption corroborates the hypothesis that CLD could be endocrine disruptor in invertebrates as already observed in vertebrates. Indeed, several previous studies have demonstrated that CLD could be an endocrine disruptor in vertebrates such as fish (Ankley et al., 1998; Donohoe and Curtis, 1996; Nimrod and Benson, 1997; Sumpter and Jobling, 1995), birds and mammals (Eroschenko, 1981), by having estrogenic properties through interaction with the estrogen-receptor system (Donohoe and Curtis, 1996; Hammond et al., 1979; Rodríguez et al., 2007). In crustaceans, various estrogenic compounds and estrogen receptor agonists (e.g. bisphenol A; nonylphenol) have been shown to act as ecdysteroid synthesis inhibitors or ecdysteroid receptor (EcR) antagonists (LeBlanc, 2007), leading to a possible decrease of ecdysteroid concentrations (Forget-Leray et al., 2005; LeBlanc, 2007; Rodríguez et al., 2007). Thus, it could be hypothesized that CLD decreased the 20-HE concentration by binding directly to ecdysteroid receptor, as a consequence of its anti-ecdysteroidal activity (Zou and Fingerman, 1999d; Zou, 2005). However, as other EDCs, CLD can also interfere the endocrine system indirectly by several mechanisms, at any step of the transduction pathway of the hormones (Hyne, 2011; Rodríguez et al., 2007). The 20-HE decrease observed here could also be explained by a modification of the excretion rate of the hormone or an inactivation of the enzyme involved in the ecdysteroid biotransformation. Because of the fact that CLD impacts the 20-HE concentration, it could therefore in the long-term disturb the molting of organisms which is induced by this hormone (Hyne, 2011; Rodríguez et al., 2007). This hypothesis is supported by the studies of Hirano et al. (2009) which have shown that low 20-HE concentration in the shrimp Americamysis bahia exposed to nonylphenol (also known to be an inhibitor of ecdysteroid activity) affected the growth of organisms. In similar way, a decrease of the 20-HE concentrations in juveniles of Daphnia magna exposed to the fungicide fenarimol was associated with abnormal development (LeBlanc, 2007; Mu and Leblanc, 2002). Snyder and Mulder (2001) have also suggested that the delay in the beginning of molting of larvae in the lobster $H$. americanus when exposed to heptachlor, probably correlated to a drop in the concentrations of circulating ecdysteroids. Moreover, knowing that crustacean reproduction is linked to the molt cycle (Hyne, 2011), disruption in the molting process could also cause disturbances in reproduction as hypothesized by Gismondi and Thomé (2014) in the amphipod, G. pulex. Indeed, it was observed that the anti-ecdysteroidal activity of nonylphenol caused a reduction in fecundity of many insects (LeBlanc et al., 2000).

Results also highlighted stronger decrease (or tendency to stronger decrease) of the 20-HE concentration in prawns exposed to $0.2 \mu \mathrm{g} \mathrm{L}^{-1}$ of CLD with time (except after 30 days of exposure), while this decrease was less obvious in prawns exposed to high CLD concentrations (i.e. 2 and $20 \mu \mathrm{g} \mathrm{L}^{-1}$ ). This observation could be explained by the fact that all receptors, through which CLD 
may exert its effects, were already occupied by CLD molecules at the exposure concentration of $0.2 \mu \mathrm{g} \mathrm{L}^{-1}$. With higher CLD concentrations required to increase the response, no additional binding can occur, and thus, the maximal effect was observed in prawns exposed to $0.2 \mu \mathrm{g} \mathrm{L}^{-1}$ (Welshons et al., 2003). Moreover, it is now well established that EDCs act at low levels (Vandenberg et al., 2012). Therefore, it can also be hypothesized that $0.02 \mu \mathrm{g} \mathrm{L}^{-1}$ of CLD is too weak to cause significant disturbances, while the $0.2 \mu \mathrm{g} \mathrm{L}^{-1}$ seems to be the lowest sufficient CLD concentration to induce effects on endocrine hormones.

\subsection{Chlordecone effects on chitobiase activity}

With regard to chitobiase activity, results highlighted no significant effects of CLD in prawns exposed for 1 or 4 days. However, after 15 days of exposure, a significant increase of the chitobiase activity was observed, but only for prawns exposed to $0.2 \mu \mathrm{gL}^{-1}$ of CLD, while a significant inhibition was observed in all CLD conditions after 30 days of exposure. In addition, unlike 20-HE results, chitobiase activity was not strongly correlated with the CLD exposure. This result is surprising due to the fact that chitinolytic enzymes are regulated by ecdysteroids in crustaceans (Zou and Fingerman, 1999d). Indeed, Zou and Fingerman (1999b) underlined that a decrease in the chitobiase activity in the fiddler crab, U. pugilator, was correlated to a reduction of ecdysteroid concentration during the molting cycle, suggesting that the chitobiase activity is regulated at least in part by 20 -HE. In the present study, based on the decrease of the 20-HE concentration, an inhibition of the chitobiase activity was therefore expected. However, the precise mechanisms linking the 20-HE concentration and the chitobiase activity are not well established yet. CLD may affect the chitobiase activity not through the effect on 20-HE concentration but maybe by disrupting several pathways and interactions with a few key receptors. This result is in line with those of Snyder and Mulder (2001). Indeed, although Snyder (1998) reported, in the lobster $H$. americanus, that although an increase in 20-HE concentration can induce the expression of cytochrome P450-dependent detoxifying enzymes (CYP45), an upregulation of the expression of this enzyme in larvae of $H$. americanus exposed to heptachlor (organochlorine pesticide) occurred together with a decrease of the 20-HE concentration. In the present study, the major absence of modification of the chitobiase activity, while a decrease of the 20-HE concentration was observed, could be explained by a direct effect of CLD on chitobiase activity through other receptors as hypothesized by Rodríguez et al. (2007). Indeed, it could be hypothesized that the inhibition of the chitobiase activity due to the decrease of the 20HE concentration could be offset by an induction of the chitobiase activity through a direct effect of CLD. Thus, these two opposite effects could result in a lack of the chitobiase activity disruption. However, results showed a decrease of the chitobiase activity after 30 days of exposure. This observation could be understood by a difference in the time of response. Indeed, as explained above, a decrease of the 20-HE concentration was observed after 15 days of exposure. 20-HE is known to induce the molt cycle, which involves the chitobiase enzyme to break down the old cuticle (Hyne, 2011). Nevertheless, no information is available on the duration of the molt cycle and the different pathway cascades in $M$. rosenbergii (i.e. from 20-HE synthesis to chitobiase activity induction). Therefore, it could be hypothesized that the consequence of the 20-HE decrease can appear later on the chitobiase activity (here, after 30 days of exposure).

The disturbance of the chitobiase activity observed here suggests a disruption of the molt cycle of $M$. rosenbergii which could have serious consequences on the individual development, due to the fact that the decapod growth is strongly linked to molt (LeBlanc, 2007). It could be hypothesized that chlordecone could affect the embryonic and juvenile development of $M$. rosenbergii, as has been observed by Zha et al. (2007) in the rotiferia B. calyciflorus where CLD could affect the reproduction process (e.g. duration of embryonic development, the juvenile period, the reproductive and post-reproductive periods).

\section{Conclusion}

This study is the first to highlight the impacts of a CLD exposure on the hormonal system of the commercial prawn, $M$. rosenbergii, by measuring the 20-HE concentration and the chitobiase activity. The results underscored that CLD is bioaccumulated in $M$. rosenbergii causing the decrease of the 20-HE concentration. In addition, an inhibition of the chitobiase activity was measured after 30 days of exposure. Although it has been documented a few times that CLD can disrupt the molting process of invertebrates, the mechanisms involved in this effect remain unknown. This work suggests that CLD could disrupt the molting process through the disturbance of the 20-HE concentration, as well as the chitobiase activity. Results allowed us to conclude that CLD could have an anti-ecdysteroidal activity, as suggested for other estrogenomimetic EDCs. Nevertheless, further studies are needed to better understand the mechanism involved in this endocrine disruption and to describe the chlordecone effects on M. rosenbergii population. It could be especially interesting to focus research on the synthesis of the 20-HE and the ecdysteroid metabolism pathways, as well as the effects of CLD on ecdysteroid receptors to confirm the anti-ecdysteroidal activity of CLD, and the designation of CLD as an EDC in invertebrates. Finally, the lack of information on the endocrine system of invertebrates makes it difficult to explain the results and their expected consequences. Therefore, future investigations should focus on the invertebrate endocrine system to refine its understanding, and to improve the assessment of effects of endocrine disruptors. Moreover, future studies might also include an assessment of the influence of molt stage on the response of organisms to xenobiotic exposure.

\section{Acknowledgments}

The present study was financially supported by grants from the National Research Agency (MACHLOMA, ANR-10-CESA-014, France) and a FNRS-F.R.I.A. grant (Fonds pour la Formation à la Recherche dans l'Industrie et dans l'Agriculture, FC 89232, Belgium). The authors thank Patrick Boucher and François Herman (OCEAN-SA) for their help in the establishment of the experiment and Catherine Adam for her technical assistance. The authors are grateful to the reviewers who helped to improve the manuscript.

\section{Appendix A. Supplementary data}

Supplementary data associated with this article can be found, in the online version, at http://dx.doi.org/10.1016/j.aquatox.2016.04. 006.

\section{References}

ATSDR, Faroon, O., Kueberuwa, S., Smith, L., Derosa, C., U.S. Department of Health and Human Services, P.H.S, 1995. Toxicological profile for mirex and chlordecone. Toxicol. Ind. Health 11, 1-195, http://dx.doi.org/10.1177/ 074823379501100601.

Ankley, G., Mihaich, E., Stahl, R., Tillitt, D., Colborn, T., McMaster, S., Miller, R. Bantle, J., Campbell, P., Denslow, N., Dickerson, R., Folmar, L., Fry, M., Giesy, J., Gray, L.E., Guiney, P., Hutchinson, T., Kennedy, S., Kramer, V., LeBlanc, G., Mayes, M., Nimrod, A., Patino, R., Peterson, R., Purdy, R., Ringer, R., Thomas, P., Touart, L., Van Der Kraak, G., Zacharewski, T., 1998. Overview of a workshop on screening methods for detecting potential (anti-)estrogenic/androgenic chemicals in wildlife. Environ. Toxicol. Chem. 17, 68-87, http://dx.doi.org/10. 1002 /etc.5620170110. 
Anon, 2008. Arrêté du 30 juin 2008 relatif aux limites maximales applicables aux résidus de chlordécone que ne doivent pas dépasser certaines denrées alimentaires d'origine végétale et animale pour être reconnues propres à la consommation humaine. JORF, 4 juillet.

Bahner, L.H., Wilson, A.J., Sheppard, J.M., Patrick, J.M., Goodman, L.R., Walsh, G.E., 1977. Kepone registered bioconcentration, accumulation, loss, and transfer through estuarine food chains. Chesap. Sci. 18, 299, http://dx.doi.org/10.2307/ 1350804.

Bocquené, G., Franco, A., 2005. Pesticide contamination of the coastline of Martinique. Mar. Pollut. Bull. 51, 612-619, http://dx.doi.org/10.1016/j. marpolbul.2005.06.026.

Bookhout, C.G., Costlow, J.D., Monroe, R., 1980. Kepone effects on larval development of mud-crab and blue-crab. Water Air Soil Pollut. 13, 57-77, http://dx.doi.org/10.1007/BF02262525.

Cabidoche, Y.M., Lesueur-Jannoyer, M., 2012. Contamination of harvested organs in root crops grown on chlordecone-polluted soils. Pedosphere 22, 562-571, http://dx.doi.org/10.1016/S1002-0160(12)60041-1.

Cabidoche, Y.-M., Lesueur-Jannoyer, M., Vannière, H., 2006. Conclusions du groupe d'étude et de prospective "Pollution par les organochlorés aux Antilles: aspects agronomiques». Contrib. CIRAD INRA.

Cabidoche, Y.M., Achard, R., Cattan, P., Clermont-Dauphin, C., Massat, F., Sansoulet, J., 2009. Long-term pollution by chlordecone of tropical volcanic soils in the French West Indies: a simple leaching model accounts for current residue. Environ. Pollut. 157, 1697-1705, http://dx.doi.org/10.1016/j.envpol.2008.12. 015.

Cailleaud, K., Budzinski, H., Le Menach, K., Souissi, S., Forget-Leray, J., 2009. Uptake and elimination of hydrophobic organic contaminants in estuarine copepods: an experimental study. Environ. Toxicol. Chem. 28, 239-246, http://dx.doi.org/ 10.1897/07-664.1.

Cavelier, N., 1980. Contamination de la Faune par les pesticides organochlorés. In: Kermarrec, A. (Ed.), Niveau actuel de la contamination des chaînes biologiques en Guadeloupe: pesticides et métaux lourds. INRA, contrat n ${ }^{\circ} \mathbf{7 8 8 3}$. Ministère de l'Environnement et du Cadre de Vie, Paris.

Chang, E.S., Bruce, M.J., 1980. Ecdysteroid titers of juvenile lobsters following molt induction. J. Exp. Zool. 214, 157-160, http://dx.doi.org/10.1002/jez. 1402140205.

Clostre, F., Woignier, T., Rangon, L., Fernandes, P., Soler, A., Lesueur-Jannoyer, M., 2013. Field validation of chlordecone soil sequestration by organic matter addition. J. Soils Sediments 14, 23-33, http://dx.doi.org/10.1007/s11368-0130790-3.

Coat, S., Bocquené, G., Godard, E., 2006. Contamination of some aquatic species with the organochlorine pesticide chlordecone in Martinique. Aquat. Living Resour. 19, 181-187, http://dx.doi.org/10.1051/alr:2006016.

Coat, S., Monti, D., Legendre, P., Bouchon, C., Massat, F., Lepoint, G., 2011. Organochlorine pollution in tropical rivers (Guadeloupe): role of ecological factors in food web bioaccumulation. Environ. Pollut. 159, 1692-1701, http:// dx.doi.org/10.1016/j.envpol.2011.02.036.

Craig, Z.R., Wang, W., Flaws, J.A., 2011. Endocrine-disrupting chemicals in ovarian function: effects on steroidogenesis, metabolism and nuclear receptor signaling. Reproduction 142, 633-646, http://dx.doi.org/10.1530/REP-11-0136.

DeFur, P.L., Crane, M., Ingersoll, C., Tattersfield, L., 1999. Endocrine Disruption in Invertebrates: Endocrinology, Testing, and Assessment. SETAC Technical Publication, Pensacola, FL.

Debier, C., Pomeroy, P.P., Dupont, C., Joiris, C., Comblin, V., Le Boulengé, E. Larondelle, Y., Thomé, J.P., 2003. Quantitative dynamics of PCB transfer from mother to pup during lactation in UK grey seals Halichoerus grypus. Mar. Ecol. Prog. Ser. 247, 237-248, http://dx.doi.org/10.3354/meps247249.

Document No SANCO/12495/2011 European Union, 2011. Method validation and quality control procedures for pesticides residues analysis in food and feed.

Dolfing, J., Novak, I., Archelas, A., MacArie, H., 2012. Gibbs free energy of formation of chlordecone and potential degradation products: implications for remediation strategies and environmental fate. Environ. Sci. Technol. 46, 8131-8139, http://dx.doi.org/10.1021/es301165p.

Donohoe, R.M., Curtis, L.R., 1996. Estrogenic activity of chlordecone, o,p'-DDT and $\mathrm{o}, \mathrm{p}^{\prime}$-DDE in juvenile rainbow trout: induction of vitellogenesis and interaction with hepatic estrogen binding sites. Aquat. Toxicol. 36, 31-52, http://dx.doi. org/10.1016/S0166-445X(96)00799-0.

Dubuisson, C., Héraud, F., Leblanc, J.-C., Gallotti, S., Flamand, C., Blateau, A., Quenel, P., Volatier, J.-L., 2007. Impact of subsistence production on the management options to reduce the food exposure of the Martinican population to Chlordecone. Regul. Toxicol. Pharmacol. 49, 5-16, http://dx.doi.org/10.1016/j. yrtph.2007.04.008.

Duchet, C., Mitie Inafuku, M., Caquet, T., Larroque, M., Franquet, E., Lagneau, C., Lagadic, L., 2011. Chitobiase activity as an indicator of altered survival, growth and reproduction in Daphnia pulex and Daphnia magna (Crustacea: Cladocera) exposed to spinosad and diflubenzuron. Ecotoxicol. Environ. Saf. 74, 800-810, http://dx.doi.org/10.1016/j.ecoenv.2010.11.001.

Duquesne, S., Riddle, M., Schulz, R., Liess, M., 2000. Effects of contaminants in the Antarctic environment-potential of the gammarid amphipod crustacean Paramorea walkeri as a biological indicator for Antarctic ecosystems based on toxicity and bioacccumulation of copper and cadmium. Aquat. Toxicol. 49, 131-143, http://dx.doi.org/10.1016/S0166-445X(99)00067-3.

Eroschenko, V.P., 1981. Estrogenic activity of the insecticide chlordecone in the reproductive tract of birds and mammals. J. Toxicol. Environ. Health 8 , 731-742, http://dx.doi.org/10.1080/15287398109530109.
Espie, P.J., Roff, J.C., 1996. A biochemical index of duration of the molt cycle for planktonic Crustacea based on the chitin-degrading enzyme, chitobiase. Oceanogr. Lit. 43, 694

Fernández-Bayo, J.D., Saison, C., Voltz, M., Disko, U., Hofmann, D., Berns, A.E., 2013. Chlordecone fate and mineralisation in a tropical soil (andosol) microcosm under aerobic conditions. Sci. Total Environ. 463-464, 395-403, http://dx.doi. org/10.1016/j.scitotenv.2013.06.044.

Forget-Leray, J., Landriau, I., Minier, C., Leboulenger, F., 2005. Impact of endocrine toxicants on survival, development, and reproduction of the estuarine copepod Eurytemora affinis (Poppe). Ecotoxicol. Environ. Saf. 60, 288-294, http://dx.doi. org/10.1016/j.ecoenv.2004.06.008.

Gaume, B., Dodet, N., Thomé, J.P., Lemoine, S., 2014. Expression of biotransformation and oxidative stress genes in the giant freshwater prawn Macrobrachium rosenbergii exposed to chlordecone. Environ. Sci. Pollut. Res., http://dx.doi.org/10.1007/s11356-014-3134-y.

Gismondi, E., Thomé, J.P., 2014. Effects of two PBDE congeners on the moulting enzymes of the freshwater amphipod Gammarus pulex. Environ. Pollut. 191, 119-125, http://dx.doi.org/10.1016/j.envpol.2014.04.017.

Giusti, A., Leprince, P., Mazzucchelli, G., Thomé, J.P., Lagadic, L., Ducrot, V., Joaquim-Justo, C., 2013. Proteomic analysis of the reproductive organs of the hermaphroditic gastropod Lymnaea stagnalis exposed to different endocrine disrupting chemicals. PLoS One 8, http://dx.doi.org/10.1371/journal.pone. 0081086.

Gomez-Catalan, J., To-Figueras, J., Rodamilans, M., Corbella, J., 1991. Transport of organochlorine residues in the rat and human blood. Arch. Environ. Contam. Toxicol. 20, 61-66, http://dx.doi.org/10.1007/BF01065329.

GREPP, 2004. Rapport d'activités 2001-2004. Programme d'actions 2005.

Guldner, L., Multigner, L., Héraud, F., Monfort, C., Pierre Thomé, J., Giusti, A., Kadhel, P., Cordier, S., 2010. Pesticide exposure of pregnant women in Guadeloupe: ability of a food frequency questionnaire to estimate blood concentration of chlordecone. Environ. Res. 110, 146-151, http://dx.doi.org/10.1016/j.envres. 2009.10.015.

Hammond, B., Katzenellenbogen, B.S., Krauthammer, N., McConnell, J., 1979. Estrogenic activity of the insecticide chlordecone (Kepone) and interaction with uterine estrogen receptors. Proc. Natl. Acad. Sci. U. S. A. 76, 6641-6645 http://dx.doi.org/10.1073/pnas.76.12.6641.

Hebel, D.K., Jones, M.B., Depledge, M.H., 1997. Responses of crustaceans to contaminant exposure: a holistic approach. Estuar. Coast. Shelf Sci. 44 177-184, http://dx.doi.org/10.1006/ecss.1996.0209.

Hirano, M., Ishibashi, H., Kim, J.W., Matsumura, N., Arizono, K., 2009. Effects of environmentally relevant concentrations of nonylphenol on growth and 20-hydroxyecdysone levels in mysid crustacean, Americamysis bahia. Comp. Biochem. Physiol. C Toxicol. Pharmacol. 149, 368-373, http://dx.doi.org/10. 1016/j.cbpc.2008.09.005.

Hyne, R.V., 2011. Review of the reproductive biology of amphipods and their endocrine regulation: identification of mechanistic pathways for reproductive toxicants. Environ. Toxicol. Chem. 30, 2647-2657, http://dx.doi.org/10.1002/ etc.673.

InVS-Inserm, 2009. Impact sanitaire de l'utilisation du chlordécone aux Antilles françaises-Recommandations pour les recherches et les actions de santé publique-Octobre 2009. Institut de veille sanitaire, mars, Saint-Maurice (Fra), pp. 96 (Available on: www.invs.sante.fr).

Jobling, S., Sumpter, J.P., 1993. Detergent components in sewage effluent are weakly oestrogenic to fish: an in vitro study using rainbow trout (Oncorhynchus mykiss) hepatocytes. Aquat. Toxicol. 27, 361-372, http://dx.doi. org/10.1016/0166-445X(93)90064-8.

Kloas, W., Urbatzka, R., Opitz, R., Würtz, S., Behrends, T., Hermelink, B., Hofmann, F., Jagnytsch, O., Kroupova, H., Lorenz, C., Neumann, N., Pietsch, C., Trubiroha, A., Van Ballegooy, C., Wiedemann, C., Lutz, I., 2009. Endocrine disruption in aquatic vertebrates. Ann. N. Y. Acad. Sci. 1163, 187-200, http://dx.doi.org/10. 1111/j.1749-6632.2009.04453.x.

Kortenkamp, A., Martin, O., Faust, M., Evans, R., Mckinlay, R., Orton, F., Rosivatz, E., 2011. State of the Art Assessment of Endocrine Disrupters. European Commission, Brussels, Belgium.

Lagarrigue, M., Lavigne, R., Tabet, E., Genet, V., Thomé, J.-P., Rondel, K., Guével, B. Multigner, L., Samson, M., Pineau, C., 2014. Localization and in situ absolute quantification of chlordecone in the mouse liver by MALDI imaging. Anal. Chem. 86, 5775-5783, http://dx.doi.org/10.1021/ac500313s.

LeBlanc, G.A., Mu, X., Rider, C.V., 2000. Embryotoxicity of the alkylphenol degradation product 4-nonylphenol to the crustacean Daphnia magna. Environ. Health Perspect. 108, 1133-1138, http://dx.doi.org/10.1289/ehp.001081133.

LeBlanc, G.A., 2007. Crustacean endocrine toxicology: a review. Ecotoxicology 16, 61-81, http://dx.doi.org/10.1007/s10646-006-0115-z.

Levillain, J., Cattan, P., Colin, F., Voltz, M., Cabidoche, Y.M., 2012. Analysis of environmental and farming factors of soil contamination by a persistent organic pollutant, chlordecone, in a banana production area of French West Indies. Agric. Ecosyst. Environ. 159, 123-132, http://dx.doi.org/10.1016/j.agee. 2012.07.005.

Matsumura, F., 1975. Toxicology of Insecticides. Plenum Press, New York.

Meyer-Reil, L.-A., Köster, M., 2000. Eutrophication of marine waters: effects on benthic microbial communities. Mar. Pollut. Bull. 41, 255-263, http://dx.doi. org/10.1016/S0025-326X(00)00114-4.

$\mathrm{Mu}, \mathrm{X}$., Leblanc, G.A., 2002. Environmental antiecdysteroids alter embryo development in the crustacean Daphnia magna. J. Exp. Zool. 292, 287-292, http://dx.doi.org/10.1002/jez.10020. 
Multigner, L., Ndong, J.R., Giusti, A., Romana, M., Delacroix-Maillard, H., Cordier, S., Jégou, B., Thome, J.P., Blanchet, P., 2010. Chlordecone exposure and risk of prostate cancer. J. Clin. Oncol. 28, 3457-3462, http://dx.doi.org/10.1200/JCO. 2009.27.2153.

Mykles, D.L., 2011. Ecdysteroid metabolism in crustaceans. J. Steroid Biochem. Mol. Biol. 127, 196-203, http://dx.doi.org/10.1016/j.jsbmb.2010.09.001.

New, M.B., 2002. Farming Freshwater Prawns: A Manual for the Culture of the Giant River Prawn (Macrobrachium rosenbergii). Food and Agriculture Organization of the United Nations.

Newhouse, K., Berner, T., Mukerjee, D., Rooney, A., 2009. IRIS Toxicological Review of Chlordecone (Kepone), U.S. Environmental Protection Agency. U.S. Environmental Protection Agency, Washington DC.

Nimmo, D.R., Bahner, L.H., Rigby, R.A., Sheppard, J.M., Wilson, A.J., 1977. Mysidopsis bahia: an estuarine species suitable for life cycle toxicity tests to determine the effects of a pollutant. Aquat. Toxicol. Hazard Eval., 305.

Nimrod, A.C., Benson, W.H., 1997. Xenobiotic interaction with and alteration of channel catfish estrogen receptor. Toxicol. Appl. Pharmacol. 147, 381-390, http://dx.doi.org/10.1006/taap.1997.8296.

Oberdörster, E., Cheek, A.O., 2001. Gender benders at the beach: endocrine disruption in marine and estuarine organisms. Environ. Toxicol. Chem. 20, 23-36, http://dx.doi.org/10.1002/etc.5620200103.

Oberdörster, E., Cottam, D.M., Wilmot, F.A., Milner, M.J., McLachlan, J.A., 1999 Interaction of PAHs and PCBs with ecdysone-dependent gene expression and cell proliferation. Toxicol. Appl. Pharmacol. 160, 101-108, http://dx.doi.org/10. 1006/taap.1999.8745.

Okumura, T., Aida, K., 2000. Fluctuations in hemolymph ecdysteroid levels during the reproductive and non-reproductive molt cycles in the giant freshwater prawn Macrobrachium rosenbergii. Fish. Sci. 66, 876-883, http://dx.doi.org/10. 1046/j.1444-2906.2000.00142.x.

Owen, R., Buxton, L., Sarkis, S., Toaspern, M., Knap, A., Depledge, M., 2002. An evaluation of hemolymph cholinesterase activities in the tropical scallop Euvola (Pecten) ziczac, for the rapid assessment of pesticide exposure. Mar. Pollut. Bull. 44, 1010-1017, http://dx.doi.org/10.1016/S0025-326X(02)00139$\mathrm{X}$.

Palma, P., Palma, V.L., Matos, C., Fernandes, R.M., Bohn, A., Soares, A.M.V.M., Barbosa, I.R., 2009. Effects of atrazine and endosulfan sulphate on the ecdysteroid system of Daphnia magna. Chemosphere 74, 676-681, http://dx. doi.org/10.1016/j.chemosphere.2008.10.021.

Radenac, G., Bocquene, G., Fichet, D., Miramand, P., 2008. Contamination of a dredged material disposal site La Rochelle Bay, France. The use of the acetylcholinesterase activity of Mytilus edulis L. as a biomarker of pesticides: the need for a critical approach. Biomarkers 3, 305-315.

Revathi, P., Munuswamy, N., 2010. Effect of tributyltin on the early embryonic development in the freshwater prawn Macrobrachium rosenbergii (De Man). Chemosphere 79, 922-927, http://dx.doi.org/10.1016/j.chemosphere.2010.03. 023.

Roberts, M.H., 1981. Kepone distribution in selected tissues of blue crabs, Callinectes sapidus, collected from the James River and Lower Chesapeake Bay. Estuaries 4, 313, http://dx.doi.org/10.2307/1352155.

Rodríguez, E.M., Medesani, D.A., Fingerman, M., 2007. Endocrine disruption in crustaceans due to pollutants: a review. Comp. Biochem. Physiol. A Mol. Integr. Physiol. 146, 661-671, http://dx.doi.org/10.1016/j.cbpa.2006.04.030.

Ross, L.G., 2001. Prawns of Japan and the World. CRC Press.

Sanders, H.O., Huckins, J., Johnson, B.T., Skaar, D., 1981. Biological effects of Kepone and mirex in freshwater invertebrates. Arch. Environ. Contam. Toxicol. 10, 531-539, http://dx.doi.org/10.1007/BF01054877.

Satapornvanit, K., Baird, D.J., Little, D.C., 2009. Laboratory toxicity test and post-exposure feeding inhibition using the giant freshwater prawn Macrobrachium rosenbergii. Chemosphere 74, 1209-1215, http://dx.doi.org/10. 1016/j.chemosphere.2008.11.033.

Schimmel, S.C., Patrick, J.M., Faas, L.F., Oglesby, J.L., Wilson, A.J., 1979. Kepone: toxicity and bioaccumulation in blue crabs. Estuar. Coasts 2, 9-15, http://dx. doi.org/10.1007/BF02823701.

Schimmel, S.C., Wilson, A.J., 1977. Acute toxicity of Kepone registered to four estuarine animals. Chesap. Sci. 18, 224, http://dx.doi.org/10.2307/1350864.

Snegaroff, J., 1977. Les résidus d'insecticides organochlorés dans les sols et les rivières de la région bananière de Guadeloupe. Phytiatr. Phytopharm. 26, 251-268

Snyder, M.J., 1998. Identification of a new cytochrome P450 family, CYP45, from the lobster, Homarus americanus, and expression following hormone and xenobiotic exposures. Arch. Biochem. Biophys. 358, 271-276, http://dx.doi. org/10.1006/abbi.1998.0878.

Snyder, M.J., Mulder, E.P., 2001. Environmental endocrine disruption in decapod crustacean larvae: hormone titers, cytochrome $\mathrm{P} 450$, and stress protein responses to heptachlor exposure. Aquat. Toxicol. 55, 177-190, http://dx.doi. org/10.1016/s0166-445x(01)00173-4.

Soetaert, A., van der Ven, K., Moens, L.N., Vandenbrouck, T., van Remortel, P., De Coen, W.M., 2007. Daphnia magna and ecotoxicogenomics: gene expression profiles of the anti-ecdysteroidal fungicide fenarimol using energy-, moltingand life stage-related cDNA libraries. Chemosphere 67, 60-71, http://dx.doi. org/10.1016/j.chemosphere.2006.09.076.
Soine, P.J., Blanke, R.V., Guzelian, P.S., Schwartz, C.C., 1982. Preferential binding of chlordecone to the protein and high density lipoprotein fractions of plasma from humans and other species. J. Toxicol. Environ. Health 9, 107-118.

Sterrett, F.S., Boss, C.A., 1977. Careless Kepone. Environ. Sci. Policy Sustain. Dev. 19 30-37, http://dx.doi.org/10.1080/00139157.1977.9928594.

Sumpter, J.P., Jobling, S., 1995. Vitellogenesis as a biomarker for estrogenic contamination of the aquatic environment. Environ. Health Perspect. 103, 173-178, http://dx.doi.org/10.1289/ehp.95103s7173.

Tabb, M.M., Blumberg, B., 2006. New modes of action for endocrine-disrupting chemicals. Mol. Endocrinol. 20, 475-482, http://dx.doi.org/10.1210/me.20040513.

Taylor, D., 1983. The significance of the accumulation of cadmium by aquatic organisms. Ecotoxicol. Environ. Saf. 7, 33-42, http://dx.doi.org/10.1016/01476513(83)90046-5.

Tillmann, M., Schulte-Oehlmann, U., Duft, M., Markert, B., Oehlmann, J., 2001. Effects of endocrine disruptors on prosobranch snails (Mollusca: Gastropoda) in the laboratory. Part III: cyproterone acetate and vinclozolin as antiandrogens. Ecotoxicology 10, 373-388, http://dx.doi.org/10.1023/ A:1012279231373.

UNEP, 2005. Proposal for Listing Chlordecone in Annex A of the Stockholm Convention on Persistent Organic Pollutants [WWW Document]. (UNEP/POPS/POPRC.1/INF/6). United Nations Environ. Program, Geneva, UNEP/POPS/POPRC.1/INF/6. 26 july 2005. URL http://www.pops.int/ documents/meetings/cop_1/chemlisting/chlordecone_f.pdf.

US-EPA, 2008. EPI Suite, v.4.0, EPA's office of pollution prevention toxics and Syracuse Research Corporation (SRC).

Van Veld, P.A., Bender, M.E., Roberts, M.H., 1984. Uptake, distribution, metabolism and clearance of chlordecone by channel catfish (Ictalurus punctatus). Aquat. Toxicol. 5, 33-49, http://dx.doi.org/10.1016/0166-445X(84)90030-4.

Vandenberg, L.N., Colborn, T., Hayes, T.B., Heindel, J.J., Jacobs, D.R., Lee, D.H., Shioda, T., Soto, A.M., vom Saal, F.S., Welshons, W.V., Zoeller, R.T., Myers, J.P., 2012. Hormones and endocrine-disrupting chemicals: low-dose effects and nonmonotonic dose responses. Endocr. Rev. 33, 378-455, http://dx.doi.org/10. 1210/er.2011-1050.

Welshons, W.V., Thayer, K.A., Judy, B.M., Taylor, J.A., Curran, E.M., vom Saal, F.S. 2003. Large effects from small exposures. I. Mechanisms for endocrine-disrupting chemicals with estrogenic activity. Environ. Health Perspect. 111, 994-1006.

Xuereb, B., Chaumot, A., Mons, R., Garric, J., Geffard, O., 2009. Acetylcholinesterase activity in Gammarus fossarum (Crustacea Amphipoda) Intrinsic variability, reference levels, and a reliable tool for field surveys. Aquat. Toxicol. 93 , 225-233, http://dx.doi.org/10.1016/j.aquatox.2009.05.006.

Xuereb, B., Bezin, L., Chaumot, A., Budzinski, H., Augagneur, S., Tutundjian, R., Garric, J., Geffard, O., 2011. Vitellogenin-like gene expression in freshwater amphipod Gammarus fossarum (Koch, 1835): functional characterization in females and potential for use as an endocrine disruption biomarker in males. Ecotoxicology 20, 1286-1299, http://dx.doi.org/10.1007/s10646-011-0685-2.

Zaldivar, J.M., Baraibar, J., 2011. A biology-based dynamic approach for the reconciliation of acute and chronic toxicity tests: application to Daphnia magna. Chemosphere 82,1547-1555, http://dx.doi.org/10.1016/j. chemosphere.2010.11.062.

Zha, C.W., Xi, Y.L., Huang, L., Zhao, L.L., 2007. Effect of sublethal exposure to chlordecone on life history characteristics of freshwater rotifer Brachionus calyciflorus pallas. Bull. Environ. Contam. Toxicol. 78, 79-83, http://dx.doi.org/ 10.1007/s00128-007-9003-3.

Zou, E., 2005. Impacts of xenobiotics on crustacean molting: the invisible endocrine disruption. Integr. Comp. Biol. 45, 33-38, http://dx.doi.org/10.1093/icb/45.1.33.

Zou, E., Bonvillain, R., 2004. Chitinase activity in the epidermis of the fiddler crab Uca pugilator, as an in vivo screen for molt-interfering xenobiotics. Comp. Biochem. Physiol. C Toxicol. Pharmacol. 139, 225-230, http://dx.doi.org/10. 1016/j.cca.2004.11.003.

Zou, E., Fingerman, M., 1999a. Chitobiase activity in the epidermis and hepatopancreas of the fiddler crab Uca pugilator during the molting cycle. Mar. Biol. 133, 97-101, http://dx.doi.org/10.1007/s002270050447.

Zou, E., Fingerman, M., 1999b. Patterns of $N$-acetyl-beta-glucosaminidase isoenzymes in the epidermis and hepatopancreas and induction of $\mathrm{N}$-acetyl-beta-glucosaminidase activity by 20-hydroxyecdysone in the fiddler crab, Uca pugilator. Comp. Biochem. Physiol. C. Pharmacol. Toxicol. Endocrinol. 124, 345-349.

Zou, E., Fingerman, M., 1999c. Effects of estrogenic agents on chitobiase activity in the epidermis and hepatopancreas of the fiddler crab, Uca pugilator. Ecotoxicol. Environ. Saf. 42, 185-190, http://dx.doi.org/10.1006/eesa.1998.1740.

Zou, E., Fingerman, M., 1999d. Effects of exposure to diethyl phthalate, 4-(tert)-octylphenol, and 2,4,5-trichlorobiphenyl on activity of chitobiase in the epidermis and hepatopancreas of the fiddler crab, Uca pugilator. Comp. Biochem. Physiol. C Pharmacol. Toxicol. Endocrinol. 122, 115-120. 